\title{
Effect of Childbirth Complications Occurrence Of Asphyxia Neonatorum
}

\author{
Yunita, Laurensia ${ }^{1}$ \\ ${ }^{1}$ Sari Mulia Midwifery Academy Banjarmasin \\ laurensia_yunita@akbidsarimulia.ac.id \\ Fadhiyah Noor Annisa ${ }^{1}$ \\ ${ }^{1}$ Sari Mulia Midwifery Academy Banjarmasin \\ Fadhiyah_noor_annisa@akbidsarimulia.ac.id \\ and Sundari ${ }^{2}$ \\ ${ }^{2}$ Sari Mulia School of Health Sciences \\ Sundari@stikessarimulia.ac.id
}

\begin{abstract}
Objective: Cause of newborn death in Indonesia, one of them which is equal to $27 \%$ of asphyxia. The risk factor of the which can cause the occurrence of asphyxia in the newborn baby are the maternal factors, fetal factors, placental factors and delivery factor. The occurrence of asphyxia in Hospital Dr. Moch. Ansari Saleh has Increased Banjarmasin in 2014 (2013 = 34.9\%, $2014=$ $58.5 \%$ ). Objective, analyzing the risk of childbirth complication with asphyxia newborns in Hospital Dr. Moch. Ansari Saleh Banjarmasin

Methods: The design used cross-sectional with 213 maternal samples. Population delivery who were all mothers in the delivery room Hospital Dr. Moch. Ansari Saleh Banjarmasin. Data collecting was conducted in December 2015 by systematic random sampling. Collecting the data using secondary data. Data analysis is univariate and bivariate analyses.

Results: The result Showed that there were correlation between maternity method $(\mathrm{p}=0.001, \mathrm{OR}=$ $2.93)$, complication of labor $(\mathrm{p}=0.001, \mathrm{OR}=3.96)$, and birth weight $(\mathrm{p}=0.001, \mathrm{OR}=6.09)$ with asphyxia neonatorum.

Conclusion: The referring decision can be made quickly intervening and precisely in order to the make the implementation of resuscitation of infants with a mother who has complications of childbirth can be performed optimally.
\end{abstract}

Keywords: Asphyxia, Birth weight, Neonatorum, Risk factor

\section{INTRODUCTION:}

In Indonesia, the which is a developing country still can not handle the maternal health problems during pregnancy and childbirth. Results Demographic and Health Survey shows that the MMR (MMR) in 2012 Increased namely 359 per $100,000 \mathrm{KH}$ from Earlier in 2007 that only 228 per 100,000 KH, while IMR only Decreased slightly to 32 per
$1,000 \mathrm{KH}$ than ever in 2007 to 34 per 1,000 $\mathrm{KH}^{[1]}$,

Maternal death due to obstetric complications during pregnancy, childbirth and postpartum death or the caused by an action taken during pregnancy, childbirth or postpartum (Direct obstetric deaths). There is also maternal mortality the caused by a disease that is not an 
obstetric complication, the which develops or gains weight due to pregnancy or childbirth (Indirect obstetric deaths) ${ }^{[2]}$.

Cycles of pregnancy, childbirth and the condition of babies born is a unity, if the pregnancy is healthy to be faced labor also would be easy, but if in a troubled pregnancy then it is likely at this stage of labor will also be problematic. Pregnant women who have a high risk such as giving birth under the age of 20 years will be a risk of miscarriage, anemia, malnutrition, hypertension, premature delivery, preeclampsia, eclampsia, haemorrhage, obstructed, prolonged labor, obstructed labor with actions such as vacuum extraction, extraction forceps and operation cesarean section and maternal death. The risk of complications that can occur in infants who are born LBW, preterm, neonatal asphyxia and perinatal mortality ${ }^{[3]}$. The main causes of death in the first week of life are complications of pregnancy and childbirth such as asphyxia, sepsis, and low birth weight. In 2009 the number of asphyxia in the world according to the World Health Organization was 19\%. In Indonesia, the cause of newborn mortality is the caused by asphyxia of $27 \%$.

Neonatal asphyxia is an infant state that cannot breathe, thereby decreasing $\mathrm{O} 2$ and increasing $\mathrm{CO} 2$ that causes adverse effects in further life [4]. Asphyxia neonatorum Occurs when the baby does not receive enough oxygen before, during or after birth. Factors that cause neonatal asphyxia factors include maternal, infant factors, placental factors, and labor factors.

The results of another study conducted in hospitals Tugurejo Semarang period January 2009-December 2010 were Obtained 4 factors related to the neonatorum namely asphyxiabirth weight babies with $\mathrm{OR}=53.7$, antepartum hemorrhage with $\mathrm{OR}=24.7$, premature rupture of membran (PROM) with $\mathrm{OR}=9.5$ breech position $\mathrm{OR}=0.1$ [5] Research conducted in 2011 at the Hospital Dr.Moewardi in Surakarta stated that PROM is associated with asphyxia with $\mathrm{r}=0,834 \mathrm{p}$ $<0.000^{[6]}$. Research in Pakistan in 2014 Showed that the factor of intrapartum, seizures in women with $\mathrm{OR}=2.895 \% \mathrm{CI}(1.5$ to 5.2$), \mathrm{PROM}$ with $\mathrm{OR}=2.895 \% \mathrm{CI}(1,2-$ 6.5), prolonged labor with $\mathrm{OR}=5.295 \% \mathrm{CI}$ (3.3 to 8.3) was Significantly associated with an Increased risk of death due to asphyxia in newborns ${ }^{[7]}$.

Dr. H. Moch Banjarmasin Ansari Saleh government hospital is used as a place of reference for cases that can not be handled by the centers of other health services. Based on the Data Obtained in the Medical Record Hospital Dr. H. Moch Ansari Saleh in Banjarmasin in 2012 newborn asphyxia $30.5 \%$, the incidence Increased in the year 2013 as many as 34.9\% of newborns with asphyxia. In 2014 the incidence of asphyxia Increased to $58.5 \%$. It is exciting Researchers to know what the risk factors related to neonatal asphyxia, it is Necessary to do research that could prove the existence of 
clear risk factors listed in the medical records of Patients that influence the occurrence of neonatal asphyxia in Dr. H. Moch Ansari Saleh Banjarmasin Hospital.

\section{METHODS}

The population in this study were all women giving birth in Delivery Room Hospital Dr. H. Moch Ansari Saleh Banjarmasin in 2014 amounted to 2020 with a sample size calculation is based on hypothesis testing two different formulas 213 Obtained proportions. The research design used was cross-sectional. There is also a disadvantage in this design that between independent variables and the dependent variables are not visible can explain where that Occurs first and cannot explain causal relationships. This research was conducted in December 2015, by the secondary collecting the data from the registers. The secondary of data the month from January to December 2014. The variables to be studied is how to birth, delivery complications, and birth weight in Dr. H. Moch Ansari Saleh Banjarmasin
Hospital, with the dependent variable of asphyxia neonatal events. In this study using a form that has been adapted to the research variables.

The research of data was collected and analyzed in two stages: analysis of univariate and bivariate analysis. The univariate analysis is used to get an idea of the magnitude of frequency distributions or proportions according to study the characteristics of all the variables. The sizes used in this analysis are absolute numbers and percentages because they are categorical the data in tabular form. In the bivariate analysis using Chi-Square because the dependent and independent variable is a categorical variable. Besides seeing the relationship and significance with $p$ values also look at the $95 \%$ level seen Odds Ratio (OR) generated to determine how much the degree of the relationship.

Result: The results of this study found that newborns who have Asphyxia Neonatorum number 129 cases (60.6\%) and who did not experience $84(39.4 \%)$.

Table 1. Distribution by Maternal Maternity, Complications of Birth, and Birth Weight

\begin{tabular}{|c|c|c|c|c|c|c|}
\hline $\begin{array}{c}\text { Characteristics of } \\
\text { Respondents }\end{array}$ & $\mathbf{n}$ & $\%$ & Mode & mean & Min & Max \\
\hline \multicolumn{7}{|l|}{ How to Maternity } \\
\hline Spontaneous & 77 & 36.2 & SC & & & \\
\hline Action & 136 & 63.8 & & & & \\
\hline \multicolumn{7}{|l|}{ Complications of Labor } \\
\hline There are complications & 128 & 60.1 & & & & \\
\hline No Complications & 85 & 39.9 & PROM & & & \\
\hline \multicolumn{7}{|l|}{ Birth Weight } \\
\hline $\begin{array}{l}\text { Less than } 2500 \text { grams } \\
\text { more than } 2500 \text { grams }\end{array}$ & $\begin{array}{c}53 \\
160\end{array}$ & $\begin{array}{l}24.9 \\
75.1\end{array}$ & $\begin{array}{l}2600 \\
\text { grams }\end{array}$ & $\begin{array}{l}2770 \\
\text { grams }\end{array}$ & $\begin{array}{l}1200 \\
\text { grams }\end{array}$ & $\begin{array}{l}4100 \\
\text { grams }\end{array}$ \\
\hline
\end{tabular}

\section{How to Maternity}

In Table 1 it can be seen most mothers give birth to the action amounted to $63.8 \%$
(60.6\% cesarean section and a vacuum of $3.2 \%$ ), whereas mothers who Gave birth spontaneously as much as $36.2 \%$. 


\section{Complications of Labor}

Maternal complications were experienced by $60.1 \%$ elderly mothers and mothers with no complications in their delivery were $39.9 \%$. The most common maternal complications experienced by the mother were premature rupture of membranes $21.1 \%, 16.4 \%$ pre-eclampsia, eclampsia $6.6 \%$, the second stage of antepartum bleeding $9.4 \%$ and $6.6 \%$.

\section{Birth Weight}

Table 1 shows that the majority of babies born to mothers had a birth weight of 2500 grams or more $(75.1 \%)$ and birth weight less than 2500 grams (24.9\%). Birth weight most of this research range from
2600 grams with an average birth weight reached 2770 grams. This research can inform you that most low birth weight is 1200 grams and most high birth weight was 4100 grams.

The results of the bivariate analysis using Chi-square test of independent variables with the dependent variable can be seen in table 2. According to table 2 , the results of analysis of the relationship between the way maternity with neonatal asphyxia was found that there were $95(69.9 \%)$ of mothers delivered to the action giving birth with neonatal asphyxia, whereas among mothers delivered spontaneously as many as $34(44.2 \%)$ infants were born asphyxiated neonatal.

Table 2. Distribution of respondents based Genesis asphyxia neonatorum

\begin{tabular}{|c|c|c|c|c|c|c|c|c|}
\hline \multirow[t]{3}{*}{ variables } & \multicolumn{4}{|c|}{$\begin{array}{c}\text { Asphyxia incident } \\
\text { Neonatorum }\end{array}$} & \multicolumn{2}{|c|}{ amount } & \multirow[t]{3}{*}{$\begin{array}{c}\text { OR } \\
(95 \% \mathrm{CI})\end{array}$} & \multirow[t]{3}{*}{ P Value } \\
\hline & \multicolumn{2}{|c|}{ Yes } & \multicolumn{2}{|c|}{ No } & \multirow[b]{2}{*}{$\mathbf{n}$} & \multirow[b]{2}{*}{$\%$} & & \\
\hline & $\mathbf{n}$ & $\%$ & $\mathbf{n}$ & $\%$ & & & & \\
\hline \multicolumn{9}{|l|}{ How to Maternity } \\
\hline Action & 95 & 69.9 & 41 & 30.1 & 136 & 100 & \multirow{2}{*}{$\begin{array}{c}2,930 \\
(1.641 \text { to } 5.234)\end{array}$} & \multirow[t]{2}{*}{0,001} \\
\hline Spontaneous & 34 & 44.2 & 43 & 55.8 & 77 & 100 & & \\
\hline \multicolumn{9}{|l|}{$\begin{array}{l}\text { Childbirth } \\
\text { complications }\end{array}$} \\
\hline \multirow{2}{*}{$\begin{array}{l}\text { There Complications } \\
\text { No Complications }\end{array}$} & 94 & 73.4 & 34 & 26.6 & 128 & 100 & \multirow{2}{*}{$\begin{array}{c}3.950 \\
(2.204 \text { to } 7.079)\end{array}$} & \multirow[t]{2}{*}{0,001} \\
\hline & 35 & 41.2 & 50 & 58.8 & 85 & 100 & & \\
\hline \multicolumn{9}{|l|}{ Birth weight } \\
\hline $\begin{array}{l}\text { Less than } 2500 \\
\text { grams }\end{array}$ & 46 & 86.8 & 7 & 13.2 & 53 & 100 & \multirow[t]{2}{*}{$\begin{array}{c}6.096 \\
(2.597 \text { to } 14.313)\end{array}$} & \multirow[t]{2}{*}{0,001} \\
\hline $2,500 \mathrm{~g}$ or more & 83 & 51.9 & 77 & 48.1 & 160 & 100 & & \\
\hline
\end{tabular}

Statistical analysis showed that $\mathrm{p}=0.001$, it can be concluded that there is a significant difference between the way the spontaneous birth mothers and maternal way with actions in asphyxia mean that there is a relationship between how maternity with neonatal asphyxia ( $\mathrm{p}<0.05)$. The results obtained by analysis of the value of $\mathrm{OR}=2.93$, which means that birth mothers have the opportunity to act to 2.93 times give birth to babies with neonatal asphyxia than mothers with a spontaneous delivery $(\mathrm{OR}=2.93 ; 95 \% \mathrm{CI}$ 1.64 to 5,23$)$. 
Mothers who experience complications of having a baby with neonatal asphyxia were 94 (73.4\%), whereas among women who did not have childbirth complications there were 35 (41.2\%) infants were born asphyxiated neonatal.

Table 2 shows that there is no significant difference between women who experience complications during labor and delivery complications are not experienced in asphyxia as such there is a relationship between antepartum hemorrhage with neonatal asphyxia $(\mathrm{p}=0.001)$. The results obtained by analysis of the value of $\mathrm{OR}=3.95$, which means that women with delivery complications have a chance of 3.95 times give birth to babies with neonatal asphyxia compared with mothers who did not experience birth complications $(\mathrm{OR}=0.34$; 95\% CI 2,20- 7.08).

Babies who are born weighing less than 2500 grams had neonatal asphyxia as many as 46 (86.8\%) and birth weight more than 2500 grams of $83(51.9 \%)$ infants were born asphyxiated neonatal.

Based on the p-value (0.001) indicates that there is a significant difference between birth weight less than 2500 grams birth weight more than 2500 grams in asphyxia as such there is a relationship between the birth weight neonatal asphyxia $(p=0.001)$. The results obtained by analysis of the value of $\mathrm{OR}=$ 6.096 , which means that the baby is born with a birth weight less than 2500 grams have the chance 6.096 times asphyxiated neonatal birth weight compared with more than $2,500 \mathrm{~g}$ (OR $=6.096 ; 95 \%$ CI 2.597 to 14.313$)$.

\section{CONCLUSION:}

Newborn asphyxia is a situation where the baby cannot breathe spontaneously and regularly soon after birth so as to reduce the $\mathrm{O} 2$ and $\mathrm{CO} 2$ increases lead to bad consequences in the lives of more ${ }^{[4]}$. As in Indonesia newborn mortality one caused by asphyxia by $27 \%{ }^{[2]}$.

The results showed there were 129 (60.6\%) were asphyxiated. Judging from the results of the study it can be concluded that asphyxia is still quite high. Handling asphyxia is very important to minimize asphyxia. Handling of asphyxia can be maximized if an unknown cause. Causes of asphyxia can be derived from maternal factors, fetal and umbilical cord. Certain conditions in pregnant women can cause uteroplacental blood circulation so that oxygen to the baby is reduced. Hypoxia baby in the womb is indicated with fetal distress can continue to be asphyxia newborns ${ }^{[3]}$. By the time the baby is born, the baby will spontaneously adjust a functional state in life outside the uterus. The period of adaptation to life outside the womb, called "Transition Period", but not all babies can adapt to life outside the womb, a baby who cannot breathe spontaneously and regularly so as to reduce $\mathrm{O} 2$ and further increase the $\mathrm{CO} 2$ that lead to bad consequences in the lives of more further ${ }^{[8]}$. The results of the bivariate analysis look three variables: how maternity, 
complications of labor and birth weight has a relationship with the incidence of neonatal asphyxia. Maternal with the action has a chance of 2.93 times give birth to babies with neonatal asphyxia than mothers with spontaneous labor. This study was conducted in line with Purworejo found that women who undergo cesarean section childbirth had 3.31 times the risk of having a baby with neonatal asphyxia than those who do not perform cesarean section $^{[12]}$. Theoretically labor with intervention measures using the tool or the provision of anesthesia on the actions of cesarean section ${ }^{[13]}$. Excessive use of anesthetic drugs in the mother that can directly cause respiratory depression, while the use of medical devices can cause trauma and intracranial hemorrhage in infants and hinder the circulation of oxygen. Caesarean section performed under certain conditions where vaginal delivery is less favorable for the safety of both mother and infant ${ }^{[14]}$.

Spontaneous vaginal delivery declared safe manner if done well because of approaching physiological. But according to the researchers, the possibility of assuming normal birth babies born asphyxiated neonatal occur because of the possibility of the mother lived deliveries are complications such as umbilical cord prolapse, cord compression also prolonged labor are causing circulatory disorders $\mathrm{O} 2$ which ultimately cause hypoxia in the fetus.

Women with delivery complications have a chance of 3.95 times give birth to babies with neonatal asphyxia compared with mothers who did not experience birth complications results are consistent with research conducted in Central Kalimantan in 2010 which said that the complications of labor in this regard include prolonged labor, obstructed and bleeding, were found at risk with $\mathrm{OR}=2.5$ times compared to uncomplicated labor. Similarly, the results of the case-control study in 2012 found that the risk of bleeding during childbirth obstructed 12.2 times and 19.8 times against the risk of perinatal mortality [13].

Complications of labor is a situation where the soul mother and fetus at risk because of disruptions as a direct result of pregnancy or childbirth $^{[2]}$. If under certain conditions in the mother suffered complications of labor will lead to hypoxia baby in the womb can occur and lead to fetal distress that can be asphyxia in newborns ${ }^{[3]}$.

Most childbirth complications experienced by respondents is premature rupture of the amniotic $21.1 \%, 16.4 \%$, and pre-eclampsia, the amniotic breach will cause oligohydramnios pressing the cord to hypoxia. The occurrence of asphyxia often preceded infection that occurs in term infants especially in premature infants, between PROM and asphyxia both influence each other ${ }^{[4]}$.

Mothers who have a history of severe preeclampsia tend to give birth to babies who experience asphyxia. Impaired fetal growth is common and when severe can cause intrapartum hypoxia. The influence of the 
fetus is associated with uteroplacental blood flow and the ability of the spiral artery to dilate as they should in pregnancy.

Vasospasm red blood cells so that the capacity of maternal oxygen decreases. The decline in mean maternal oxygen hypoxia in the mother. Hypoxia in the mother will cause hypoxia in the fetus ${ }^{[14]}$,

Birth complications can be prevented, one of the most effective ways to monitor the presence of complications is early detection of high-risk pregnancies, by conducting regular prenatal care and quality. The minimum antenatal done 4 times that at the age of firsttrimester pregnancy, second trimester and twice in the third trimester of pregnancy, and only then if the pregnancy is normal. But it's good pregnancy tests done once a month until the age of 6 months, twice a month at the age of 7-8 months and once a week when the thread 9 months of gestation. Because basically, all pregnancies are risky so early detection / early warning should be performed in all pregnancies, not only risk pregnancies only. Early detection of high-risk pregnancies requires attention earnest, of course, of the resources and adequate facilities to accommodate cases of referrals in each level of service.

Impact of babies born with a low birth weight often experience some problems in the systems of the body, because the body is not a stable condition. The results of this study said babies born with birth weight less than 2500 grams have the chance 6.096 times asphyxiated neonatal birth weight compared with more than 2500 grams. Babies born weighing less than 2500 grams is likely to occur because of complications during pregnancy so gestation the fetus is not mature, and if a set of conditions required to do so severe birth of pregnancy termination has not been sufficient. The second possibility for the current nutritional status of pregnant women, where the maternal intake determines the development and growth of the fetus in the womb. If the mother during pregnancy skinny and not gain weight (down to $10 \mathrm{~kg}$ ) the risk of LBW births will be high. For pregnant women, basically all require additional nutrients, but which is often a shortage of energy is protein and some minerals such as iron and calcium. Energy needs for normal pregnancies should be added about 80,000 calories over a period of approximately 280 days. This means an additional need of approximately 300 extra calories per day during pregnancy ${ }^{[16]}$.

The information can be given in this study if a proportion of fewer than 2500 grams birth weight is only $24.9 \%$, while the risk of possible baby asphyxiated neonatal times 5 times riskier than birth weight more than 2500 grams. This means that although the incidence of birth weight less than 2500 grams small but the baby's risk of neonatal asphyxia occurred great, so the need for vigilance of health workers in dealing with the condition.

This is where the importance of prenatal care because by doing prenatal care and effective 
quality so pregnant women will receive supervision and protection for early detection of abnormalities in pregnancy and prepare a healthy pregnancy, so if it is likely detected the estimated weight of the fetus that is not in accordance with the gestational age can immediate action to improve fetal weight such as improved nutrition of pregnant women.

Conclusion: Proporsi neonatal asphyxia in 2014 at the Hospital Dr. H. Moch. Banjarmasin Ansari Saleh as much as 61\%. In this study, there is a relationship with the way maternity neonatal asphyxia

\section{REFERENCE}

1. SDKI, Laporan Pendahuluan Badan Pusat Statistik. Jakarta: BKKBN; 2012.

2. Depkes RI. Profil Kesehatan Indonesia 2007. Jakarta: Depkes RI; 2008

3. Prawirohardjo, Sarwono. Ilmu Kebidanan. Jakarta : Yayasan Bina Pustaka Sarwono Prawirohardjo; 2008

4. Manuaba, dkk. Gawat Darurat Obstetri Ginekologi dan Obstetri Ginekologi Sosial untuk Profesi Bidan. Jakarta: EGC; 2008.

5. Gilang, dkk, Faktor-faktor yang berhubungan dengan kejadian Asfiksia Neonatorum (Studi di RSUD Tugurejo Semarang). Fakultas Kedokteran, Universitas Muhammadiyah Semarang; 2010

6. Widaryati, dkk. The Coherence Factors of Happen To The Neonatorum In The Peryntologhy Rooms In RSUD Dr. Moewardi Of Surakarta, Jurnal Ilmu Keperawatan Indonesia; 2011. Vol.1,No. 1.

7. Tabassum F, et al. Risk Factors Associated With Birth Asphyxia In Rural District Matiari, Pakistan: A Case Control Study. Internasional Journal of Clinical Medicine, $5,1430-1441 ; 2014$ $(\mathrm{p}=0.001)$, where mothers delivered by the action has a chance of 2.93 times give birth to babies with neonatal asphyxia than mothers with spontaneous labor.

There is a relationship between birth complications with neonatal asphyxia, with 3.95 times the chance of women with delivery complications of having a baby with neonatal asphyxia. The results of the analysis of birth weight $\mathrm{p}=0.001$ and $\mathrm{OR}=6.09$, which means there is a relationship between the birth weight neonatal asphyxia with odds of 6.09 times the weight of babies born less than 2500 grams had neonatal asphyxia.

8. Rukayah, Ai Yeyeh, dkk. Asuhan Neonatus Bayi dan Anak Balita. Trans Info Media. Jakarta; 2010

9. Fahrudin, Analisis Beberapa Faktor Risiko Kejadian Asfiksia Neonatorum di Kanupaten Purworedjo. Tesis; Program Pasca Sarjana Univarsitas Diponegoro, Semarang; 2003.

10. Maryunani, Anik dan Nurhayati, Asuhan Kegawatdaruratan dan Penyulit pada Neonatus, Jakarta: Trans Info Media; 2009

11. Wiknjosastro, H., Saifuddin, A.B., Rachimhadhi, T., Ilmu Kebidanan.World Health Organization, Geneva; 2005

12. Aisyan S.D.S, dkk, Hubungan Antara Status Sosial Ekonomi Keluarga Dengan Kematian Perinatal di Wilayah Kerja Puskesmas Baamang Unit II Sampit Kalimantan Tengah Januari-April 2010, Journal Kesmas Universitas Ahmad Dahlan, 5(1), 31-40; 2010

13. Bayou, G dan Berhan, Y, Perinatal Mortality dan associated risk factors: a case control study, Ethiop Health Sci, 153-162; 2012

14. Bobak M. Irene. Buku Ajar Keperawatan Maternitas Edisi 4. Jakarta: EGC; 2005 
15. Proverawati Atikah dan Ismawati Cahyo S, BBLR: Berat Badan Lahir Rendah. Yogyakarta: Nuha Medika; 2010
16. Budianto, Agus K, Dasar-dasar Ilmu Gizi: Malang: UMM Press; 2009 